\title{
Effects of Amentoflavone on Anti-inflammation and Cytoprotection
}

\author{
Songjeong Lee ${ }^{1}$, Hyo Sun $\mathrm{Han}^{2}$, In-Sook $\mathrm{An}^{2}$, Kyu Joong $\mathrm{Ahn}^{3 *}$ \\ ${ }^{1}$ Department of Biological Engineering, Konkuk University, Seoul, Korea \\ ${ }^{2}$ Korea Institute for Skin and Clinical Sciences, Cheongju-si, Chungcheongbuk-do, Korea \\ ${ }^{3}$ Department of Dermatology, Konkuk University School of Medicine, Seoul, Korea
}

*Corresponding author: Kyu Joong Ahn, Department of Dermatology, Konkuk University School of Medicine, 120

Neungdong-ro, Gwangjin-gu,

Seoul 05029, Korea

Tel.: +82 220305181

Fax: +82 220305179

Email: kjahn@kuh.ac.kr

Received May 17, 2016

Revised June 1, 2016

Accepted June 7, 2016

Published June 30, 2016

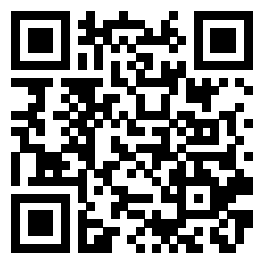

\begin{abstract}
Purpose: The purpose of this study was to verify the potential of amentoflavone as a material of cosmetic and medicine in oxidative stress conditions by confirming the effects of anti-inflammation and cytoprotection. Methods: To investigate the anti-inflammatory effects of amentoflavone, the expression of inflammatory cytokines such as TNF$\alpha$ and $I L-6$ was measured by qRT-PCR. Additionally, we performed NF$\kappa \mathrm{B}$ promoter luciferase assay to check the expression of $\mathrm{NF}-\kappa \mathrm{B}$. To confirm the cytoprotective effects, p53 siRNA transfection was conducted to determine the relation between $p 53$ and $14-3-3 \sigma$. Moreover, we performed cell cycle analysis to examine the effect of amentoflavone

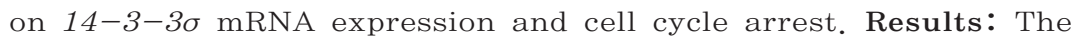
expression of inflammatory factors such as $\mathrm{TNF}-\alpha$, IL-6, and $\mathrm{NF}-\kappa$ $\mathrm{B}$ was decreased in a dose dependent manner. In case of cytoprotection, amentoflavone reduced the expression of p53 mRNA. We confirmed the positive correlation between $p 53$ and $14-3-3 \sigma$ by $p 53$ siRNA transfection. As the expression of $14-3-3 \sigma$ mRNA was decreased by amentoflavone, the cell cycle progression was restored from the cell cycle arrest. Conclusion: As mentioned above, amentoflavone decreased the expression of inflammatory and cell-damaging factors, and restored the cell cycle progression. Consequently, we found out that amentoflavone can be a valuable material possessing effects of anti-inflammation and cytoprotection in cosmetic and medicine.
\end{abstract}

Keywords: Amentoflavone, Anti-inflammation, Cytoprotection, Oxidative stress, Human dermal fibroblast

\section{Introduction}

피부에 다양한 산화 스트레스(oxidative stress)가 증가하 면 피부 생리학적 기능이 무너져 피부암(skin cancer), 노화 (senescence), 홍반(erythema), 부종(edema)과 같은 염증반응 (inflammation)이 발생한다(Kim \& Kim, 2015), 특히 염증반 응은 대식세포(macrophage)나 단핵구(monocyte)와 같은 면역 세포 내에서 신호전달 매개체인 전사인자의 활성화를 통해 염 증 관련 유전자들이 발현됨으로써 이루어진다. Macrophage는 lipopolysaccharide (LPS) 또는 interferon- $\gamma(\mathrm{IFN}-\gamma)$ 와 같은 자극에 의해 염증반응의 전사인자인 nuclear factor kappa- light-chain-enhancer of activated B cells $(\mathrm{NF}-\kappa \mathrm{B})$ 를 활성화시키며, 그 결과 inducible nitric oxide synthase (iNOS), cyclooxygenase -2 (COX-2), nitric oxide (NO), prostaglandins (PGs)를 생성시켜 염증을 일으킨다(Nathan, 1987).

$\mathrm{NF}-\kappa \mathrm{B}$ 는 염증성 및 산화성 반응에 관여하는 대표적인 전사 인자로(Mazière et al., 1999; Rostasy et al., 2000; Nomoto et al., 2001) 세포 증식, 성장, 염증반응, 세포 부착 등을 조절하며, 주로 저해 단백질인 inhibitor kappa B (IkB)와 복합체를 이루 어 불활성 상태로 존재하다가 분열촉진인자인 inflammation, cytokine, ultraviolet rays (UV), ionization, reactive oxygen species (ROS), bacteria, LPS 등의 자극을 받으면 
$\mathrm{I} \kappa \mathrm{B}$ 는 빠르게 인산화되어 분해된다(Baeuerle \& Henkel, 1994). I $\kappa \mathrm{B}$ 가 분리됨으로써 활성화된 $\mathrm{NF}-\kappa \mathrm{B}$ 는 핵으로 이동하여 interleukin-6 (IL-6), tumor necrosis factoralpha $(\mathrm{TNF}-\alpha)$ 등 염증반응을 유도하는 다양한 유전자들 을 발현시킨다(Longley et al., 1988; Ansel et al., 1990; Baeuerle, 1998; Oh et al., 2004).

산화 스트레스를 비롯한 다양한 자극이 발생하면 암 억제 유 전자(tumor suppressor gene)인 p53은 세포 내에서 다양 한 역할을 수행한다. 세포가 견딜 수 있는 수준의 자극을 받는 경우, p53은 세포의 성장 주기를 조절하거나(Levine, 1997; Miliani de Marval \& Zhang, 2011), DNA 수선과정에 참여 함으로써(Hwang et al., 1999) 세포의 생존을 유도하기도 하 고, 엄청난 손상을 주는 수준의 자극에 대해서는 개체 보호 를 위하여 프로그램화 되어있는 apoptosis를 유도하기도 한다 (Miyashita et al., 1994). 그러나 p53의 역할은 매우 다양해서 자극의 종류와 세포의 종류, 자극의 세기 그리고 배양 조건에 따라서 매우 다양한 세포 내 반응을 보이게 된다.

$\mathrm{p} 53$ 은 세포 자극이 없는 상태에서 murine double minute 2 (MDM2)에 의하여 nuclear export 되어 세포질에서 ubiquitination 현상에 의해 분해되지만(Jones et al., 1995; Montes de Oca Luna et al., 1995), 과도한 세포자극이 발 생한 경우, 손상된 DNA는 ataxia-telangiectasia mutated (ATM)과 ATM-related protein (ATR)을 활성화 시키고, 활 성화된 ATM/ATR은 전사인자인 $\mathrm{p} 53$ 을 활성화시킨다(Smits $\&$ Medema, 2001). 그리하여 p53은 downstream target 인 $p 21,14-3-3 \sigma$, growth arrest and DNA-damage-45a $(G A D D 45 \alpha)$ 와 같은 다양한 유전자의 발현을 조절한다(Brown et al., 1997; Kortlever et al., 2006). 14-3-3б는 cyclindependent kinase 2 (CDK2) 및 cyclin-dependent kinase 4 (CDK4)와 결합하고, 세포질 내 cdc2/cyclin B1 복합체와 $\mathrm{cdc} 25 \mathrm{c}$ 의 결합을 방해함으로써 세포주기(cell cycle) 진행의 억 제자 역할을 한다. 따라서 14-3-30의 기능 소실은 G2/M기와 $\mathrm{G} 1 / \mathrm{S}$ 기의 체크포인트(checkpoint) 기능 손상을 통한 악성 변 환에 기여하게 된다(Rothblum-Oviatt et al., 2001).

Amentoflavone은 플라보노이드 2 분자가 결합한 biflavonoid 로서, 항암(Banerjee et al., 2002a; Lee et al., 2013), 혈관
신생 억제(Guruvayoorappan \& Kuttan, 2008), 항진균(Jung et al., 2006; Hwang et al., 2013), 항조로증(Park et al., 2011), 지방산 합성 억제(Wilsky et al., 2012), 항우울제 및 항 불안(Ishola et al., 2012), 항염(Kim et al., 1998; Banerjee et al., 2002b; Woo et al., 2005; Ishola et al., 2013) 등의 연구가 보고된 바 있다.

한편 본 연구자들은 최근 발표한 amentoflavone의 항산화 및 항주름 효과(Lee \& An, 2016)에 관한 연구결과를 토대로, amentoflavone의 항염 및 세포 보호에 대한 연구를 진행하였 다. 산화 스트레스 상태에서, $p 53,14-3-3 \sigma$ 및 $T N F-\alpha, I L-$ $6, N F-\kappa B$ 의 유전자 발현 변화와 Cell cycle analysis를 통해 amentoflavone의 항염 및 세포 보호 효과를 확인하여 화장품, 의약품 원료로서의 가능성을 검증하고자 한다.

\section{Methods}

\section{Quantitative real-time PCR}

$\mathrm{H}_{2} \mathrm{O}_{2}$ 와 amentoflavone에 의한 유전자 변화를 확인하기 위 하여, $60 \mathrm{~mm}$ 세포배양 접시에 $2 \times 10^{5}$ cells/well의 농도로 normal human dermal fibroblast (NHDF)를 배양하였다. Amentoflavone 및 $\mathrm{H}_{2} \mathrm{O}_{2}$ 처리농도는 Lee \& An (2016)의 연구 에서 cell viability 확인을 통해 설정한 적정농도로 진행하였다. $\mathrm{NHDF}$ 세포에 amentoflavone을 $5,10,15 \mu \mathrm{M}$ 농도로 $3 \mathrm{~h}$ 동 안 전처리 한 후 $0.2 \mathrm{mM} \mathrm{H}_{2} \mathrm{O}_{2}$ 를 처리하여 $24 \mathrm{~h}$ 동안 배양한 뒤, 세포를 수확하여 RNA를 추출하였다. 추출된 RNA를 이용 하여 $1 \mu \mathrm{g}$ RNA, $0.5 \mathrm{ng}$ oligo dT18, diethylpyrocarbonate (DEPC, Biopure, UK)를 total $10 \mu \mathrm{L}$ 로 제조 후 $70^{\circ} \mathrm{C}$ 에서 $10 \mathrm{~min}$ 동안 처리하여 RNA 변성을 유도한 다음 $\mathrm{M}-\mathrm{MLV}$ reverse transcriptase (Enzynomics, Korea)을 이용하여 $37^{\circ} \mathrm{C}$ 에서 $1 \mathrm{~h}$ 반응시켜 $\mathrm{cDNA}$ 를 합성하였다. $\mathrm{cDNA}$ 를 주형 으로 Quantitative real-time PCR (qRT-PCR)을 사용하여 amentoflavone에 의해 세포 내에서 일어나는 전사적인 유전 자 발현 변화를 정량적으로 확인하였다. $\mathrm{qRT}-\mathrm{PCR}$ 은 $\mathrm{HOT}$ FIREPol EvaGreen PCR Mix Plus (Solis BioDyne, Estonia), 1 pmole forward primer, 1 pmole reverse primer, $10 \mathrm{ng}$

Table 1. Primers used in qRT-PCR

\begin{tabular}{lll}
\hline Gene & Forward primer $\left(5^{\prime} \rightarrow 3^{\prime}\right)$ & Reverse primer $\left(5^{\prime} \rightarrow 3^{\prime}\right)$ \\
\hline$I L-6$ & TAACAGTTCCTGCATGGGCGGC & AGGACAGGCACAAACACGCACC \\
$T N F-\alpha$ & CCCAGGGACCTCTCTCTAATC & GGTTTGCTACAACATGGGCTACA \\
$p 53$ & GGTCTGGCCCCTCCTCAGCA & TGCCGCCCATGCAGGAACTG \\
$14-3-3 \sigma$ & GTGTGTCCCCAGAGCATGG & ACCTTCTCCCGGTACTCACG \\
$\beta-$ actin & GGATTCCTATGTGGGCGACGA & CGCTCGGTGAGGATCTTCATG \\
\hline
\end{tabular}


$\mathrm{cDNA}$ 를 혼합하여 반응액을 만들어 Linegene $\mathrm{K}$ (BioER, China)를 이용하여 반응을 진행하였다. 반응의 세부 과정은 $94^{\circ} \mathrm{C}$ 에서 $3 \mathrm{~min}$ 동안 denaturation 후, denaturation $\left(94^{\circ} \mathrm{C}\right.$, $30 \mathrm{~s})$, annealing $\left(58^{\circ} \mathrm{C}, 30 \mathrm{~s}\right)$, polymerization $\left(72^{\circ} \mathrm{C}, 30 \mathrm{~s}\right)$ 을 40 cycle 수행하여 PCR을 진행하였다. PCR의 유효성은 melting curve로 검증하였고, 각 유전자의 발현은 $\beta$-actin의 발현을 표준화하여 비교분석 하였으며, 실험에 사용된 primer는 Table 1과 같다.

\section{NF-kB promoter luciferase assay}

Amentoflavone이 $\mathrm{NF}-\kappa \mathrm{B}$ 전사 활성에 대해 미치는 영향을 확인하기 위하여 $\mathrm{NF}-\kappa \mathrm{B}$ promoter luciferase assay를 수행 하였다. 본 실험에서는 promoter 부분에 $N F-\kappa B$ promoter consensus sequence를 가진 reporter 유전자(luciferase 유 전자)가 내재되어 있는 $\mathrm{NF}-\kappa \mathrm{B}$ reporter $\mathrm{NIH}-3 \mathrm{~T} 3$ stable cell line (Panomics, USA)을 사용하였다. NF- $\mathrm{B}$ reporter $\mathrm{NIH}-3 \mathrm{~T} 3$ stable cell을 $60 \mathrm{~mm}$ 배양접시에 $2 \times 10^{5}$ cell/well의 농도로 접종하여 $24 \mathrm{~h}$ 동안 배양 후, amentoflavone을 5,10 , $15 \mu \mathrm{M}$ 농도로 $3 \mathrm{~h}$ 동안 전처리 한 후 $0.2 \mathrm{mM} \mathrm{H}_{2} \mathrm{O}_{2}$ 를 처리 하여 $24 \mathrm{~h}$ 추가 배양하였다. 배양된 세포를 수확하여 passive lysis buffer (Promega, USA)를 첨가하고 ice에서 $10 \mathrm{~min}$ 동 안 방치하여 용해한 다음 $12,000 \mathrm{rpm}, 4^{\circ} \mathrm{C}$ 로 $30 \mathrm{~min}$ 원심분리 하여 상등액을 회수하고 동량의 단백질이 포함된 시료군을 각 각 $80 \mu \mathrm{L}$ 씩 black 96 well plate에 넣은 후 luciferin (Promega, USA)을 첨가하여 혼합하였다. Luciferin은 빛에 민감하기 때 문에 시료에 첨가한 직후 Luminometer (Veritas, USA)를 이 용하여 luciferin의 발광 정도를 측정하였다.

\section{3. $p 53$ siRNA transfection}

$\mathrm{NHDF}$ 에 amentoflavone과 $\mathrm{H}_{2} \mathrm{O}_{2}$ 를 처리하였을 때, $p 53$ $\mathrm{mRNA}$ 변화 및 $p 53$ 과 $14-3-3 \sigma$ 와의 관계를 확인하고자 p53 siRNA (Santa Cruz, USA)를 이용하였다. RNAi max (Invitrogen, USA)를 사용하여 형질주입(transfection) 시켰으 며, control로 negative scramble siRNA를 이용하였다. NHDF 에서 $p 53$ siRNA가 $p 53$ 및 14-3-3o의 발현을 억제하는지 검증하기 위해 $\mathrm{qRT}-\mathrm{PCR}$ 을 통해 측정하였다.

\section{Cell cycle analysis}

세포주기를 분석하기 위한 방법으로 sub G1, G1, S, G2/M기의 세포수를 측정하였다. NHDF 세포를 $2 \times 10^{5} \mathrm{cell} / \mathrm{well}$ 의 농도로 $60 \mathrm{~mm}$ 배양 접시에 접종 후 $24 \mathrm{~h}$ 배양한 다음 amentoflavone 을 $5,10,15 \mu \mathrm{M}$ 농도로 각각 처리하고 $0.2 \mathrm{mM} \mathrm{H}_{2} \mathrm{O}_{2}$ 를 처리한 후 $24 \mathrm{~h}$ 동안 배양하였다. 배양한 세포를 수확 후 5,000 rpm, $4{ }^{\circ} \mathrm{C}$ 조건으로 $5 \mathrm{~min}$ 동안 원심분리하여 세포를 침전시켰다.
상등액을 제거하고 PBS $300 \mu \mathrm{L}$ 로 cell pellet을 풀어준 다음 vortexing 하면서 absolute ethanol $700 \mu \mathrm{L}$ 를 서서히 첨가하 여 $4^{\circ} \mathrm{C}$ 의 조건에서 $3 \mathrm{~h}$ 이상 냉장 보관하여 세포를 고정시켰다. $\mathrm{PBS} 1 \mathrm{~mL}$ 를 첨가한 다음 $5,000 \mathrm{rpm}, 4^{\circ} \mathrm{C}$ 조건으로 $5 \mathrm{~min}$ 동안 원심분리하여 상등액을 제거하고, propidium iodide staining buffer (Propidium iodide $50 \mu \mathrm{g} / \mathrm{mL}$, RNase $0.1 \mu$ g/mL, 0.05\% Triton X-100; all from Sigma-Aldrich) 200 $\mu \mathrm{L}$ 을 넣어 pellet을 풀어준 뒤 $37^{\circ} \mathrm{C}$ 에서 $1 \mathrm{~h}$ 동안 정지하였다. 그 후 $\mathrm{NHDF}$ 를 $5,000 \mathrm{rpm}, 4^{\circ} \mathrm{C}$ 조건으로 $5 \mathrm{~min}$ 동안 원심분 리하여 상등액을 제거하고 $\mathrm{PBS}$ 로 세척한 다음 $\mathrm{PBS} 1 \mathrm{~mL}$ 로 pellet을 풀어준 뒤 flow cytometry로 각 세포주기의 세포수 를 측정하였다.

\section{Statistical analysis}

모든 실험들은 독립적으로 3 회 반복 수행하였으며, 실험결 과는 평균 \pm 표준 편차로 나타내었다. 차이의 유의성은 SPSS version 17.0 을 이용하여 분석하였다. $p$ 값이 0.05 이하인 경우 통계적으로 유의하다고 분석하였다.

\section{Results and Discussion}

\section{Anti-inflammatory effects of amentoflavone}

$\mathrm{TNF}-\alpha$ 는 염증반응의 유도인자이며 면역반응의 조절인자로 서, 미생물 감염 시 발현량이 증가하고, 식세포의 cytokine 분비 증가를 유도하여 미생물에 대한 숙주세포의 항상성을 유지하 는 중요한 방어기전 역할을 담당한다(Agarwal et al., 1988). 한편 대식세포, 단핵구, $\mathrm{T}$ 림프구, $\mathrm{B}$ 림프구, 기타 일부 세포 에서 생성되는 $\mathrm{IL}-6$ 는 $\mathrm{TNF}-\alpha$ 및 $\mathrm{IL}-1$ 과 함께 급성기 단백 반응의 유도체로서 소염제(anti-inflammatory)와 염증 전 (pro-inflammatory) cytokine으로 알려져 있으며(Opal \& DePalo, 2000), cytokine으로서 면역작용, 감염 및 염증반 응 등 다양한 기능을 한다. Inflammatory cytokine인 TNF$\alpha$ 와 $I L-6$ 의 mRNA 발현 변화를 통해서 amentoflavone 의 항염 효과에 대해서 확인하고자 $\mathrm{qRT}-\mathrm{PCR}$ 를 수행하였다. $T N F-\alpha$ 의 경우 산화 스트레스 유발인자인 $\mathrm{H}_{2} \mathrm{O}_{2}$ 처리 시 $\mathrm{H}_{2} \mathrm{O}_{2}$ 와 amentoflavone을 처리하지 않은 대조군에 비해 mRNA 발현량이 6.9배 증가한 반면, amentoflavone을 $5,10,15 \mu$ $\mathrm{M}$ 처리한 경우 5.4 배, 4.0배, 2.5배의 발현량으로 유의성 있 게 감소하였다(Figure $1 \mathrm{~A}$ ). $\mathrm{IL}-6$ 의 경우 $\mathrm{H}_{2} \mathrm{O}_{2}$ 처리 시 대조군 에 비해 7.4배 증가하였으나 amentoflavone을 $5,10,15 \mu \mathrm{M}$ 처리한 결과, 5.0 배, 3.8 배, 2.9 배로 농도의존적으로 $\mathrm{mRNA}$ 의 발현량이 감소됨을 확인하였다(Figure $1 \mathrm{~B})$. 상기 결과를 통 해 amentoflavone은 염증반응에 관여하는 인자인 $T N F-\alpha$ 와 

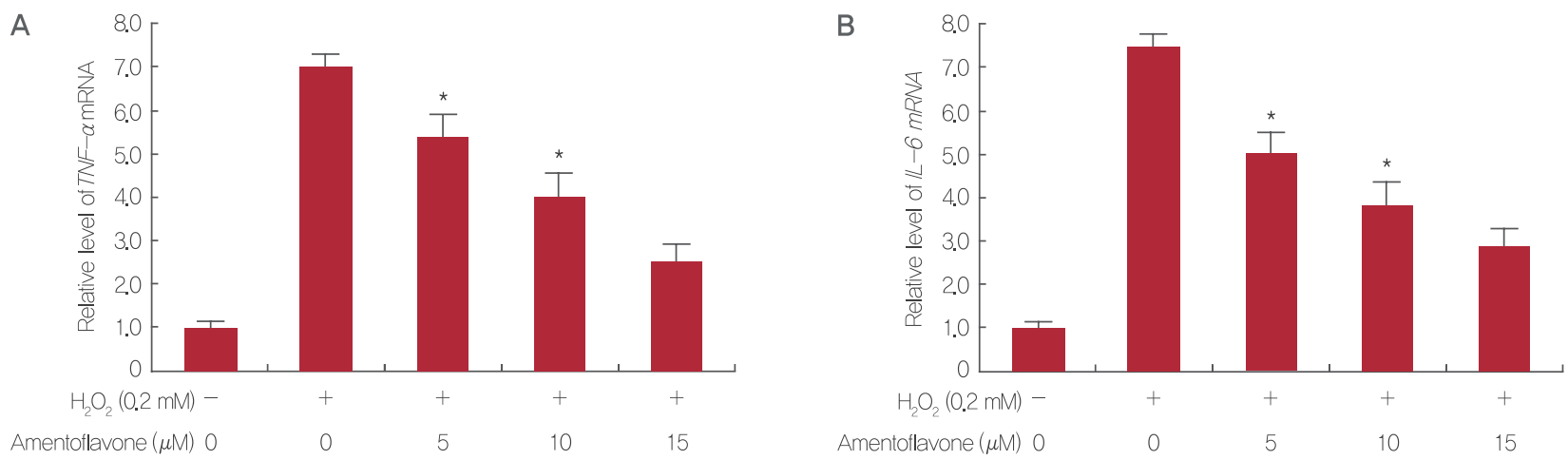

Figure 1. Effects of amentoflavone on expression of inflammatory cytokines.

The expression of inflammatory cytokines such as TNF- $\alpha$ and $I L-6$ was measured with qRT-PCR. Prior to $0.2 \mathrm{mM} \mathrm{H}_{2} \mathrm{O}_{2}$, NHDF cells were pre-treated with various concentrations of amentoflavone. (A) The expression of TNF- $\alpha$ mRNA was decreased by amentoflavone. (B) The expression of $I L-6$ mRNA was reduced in a dose-dependent manner. Values represent the mean \pm S.D. of three independent experiments. The Student's t-test was performed to determine statistical significance $\left({ }^{*} p<.05\right)$.

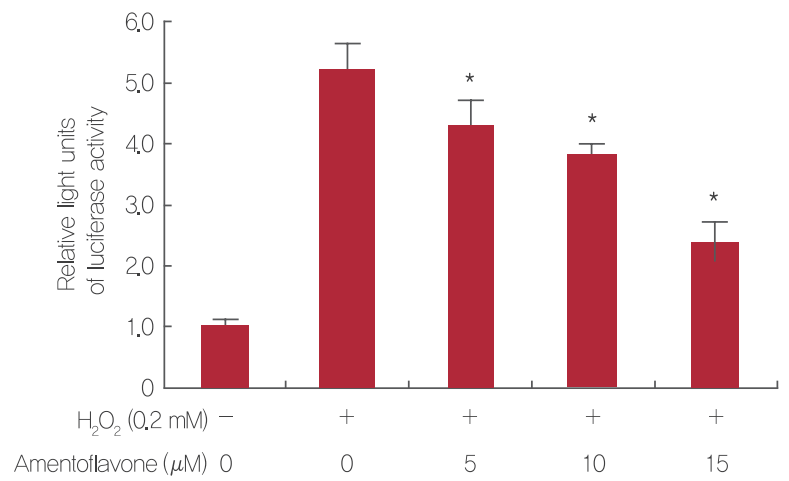

Figure 2. Effects of amentoflavone on NF-kB activation. The expression of $\mathrm{NF}-\mathrm{kB}$ was determined by $\mathrm{NF}-\mathrm{kB}$ promoter luciferase assay on $\mathrm{NHH}-3 \mathrm{~T} 3$ cells. The cells were pretreated with various concentrations of amentoflavone before the treatment of $0.2 \mathrm{mM} \mathrm{H}_{2} \mathrm{O}_{2}$. After further incubation, the amount of light made from luciferin was measured. Values represent the mean \pm S.D. of three independent experiments. The Student's t-test was performed to determine statistical significance $\left({ }^{*} p<.05\right)$.

$I L-6$ 의 발현을 유전자 수준에서 억제함으로써 항염 효과를 나타내는 것으로 판단된다.

\section{Effects of amentoflavone on NF- $\mathrm{kB}$ activation}

염증반응으로 인하여 $\mathrm{NF}-\kappa \mathrm{B}$ 가 활성화 되면, $\mathrm{NF}-\kappa \mathrm{B}$ 는 핵 으로 이동하여 전사인자로서 $\mathrm{IL}-1, \mathrm{IL}-6, \mathrm{IL}-8, \mathrm{TNF}-\alpha$ 와 같 은 pro-inflammatory cytokines의 전사를 촉진한다. NF$\kappa \mathrm{B}$ 는 세포의 성장 및 분화, 염증반응, 면역반응에 중요한 유전자들의 발현을 조절하는 전사조절인자이며, 최근에는 세포의 성장을 조절하는 물질로 밝혀졌다(Radák et al.,

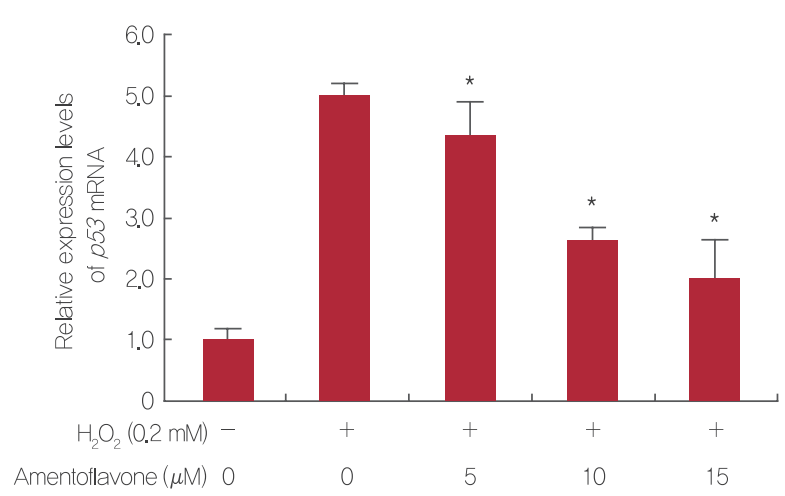

Figure 3. Effects of amentoflavone on p53 mRNA expression.

The expression of $p 53$ mRNA was measured by qRT-PCR. Amentoflavone was treated with various concentrations before the treatment of $0.2 \mathrm{mM} \mathrm{H}_{2} \mathrm{O}_{2}$. The mRNA expression was inhibited by amentoflavone in a dose-dependent manner. Values represent the mean \pm S.D. of three independent experiments. The Student's t-test was performed to determine statistical significance $\left({ }^{*} p<.05\right)$.

2004). Amentoflavone이 inflammatory cytokines 전사 를 조절하는 $\mathrm{NF}-\mathrm{kB}$ 의 발현에 미치는 영향을 확인하기 위 해, NF- $\mathrm{NB}$ promoter luciferase assay를 수행하였다. 그 결과, $0.2 \mathrm{mM} \mathrm{H}_{2} \mathrm{O}_{2}$ 를 처리하여 산화 스트레스를 유발 한 군이 $\mathrm{H}_{2} \mathrm{O}_{2}$ 와 amentoflavone을 처리하지 않은 대조군에 비해 luciferin의 발광이 5.6배 증가함을 확인함으로써 $\mathrm{H}_{2} \mathrm{O}_{2}$ 를 통해 $\mathrm{NF}-\kappa \mathrm{B}$ 의 발현이 활성화됨을 알 수 있었다. 한편 amentoflavone을 5, 10, $15 \mu \mathrm{M}$ 농도로 처리한 경우, $\mathrm{NF}-\kappa \mathrm{B}$ 의 활성을 나타내는 luciferin의 발광 정도가 각각 4.2 배, 3.7 배, 2.3 배로 농도의존적으로 감소함을 확인할 수 있었다(Figure 2). 
A
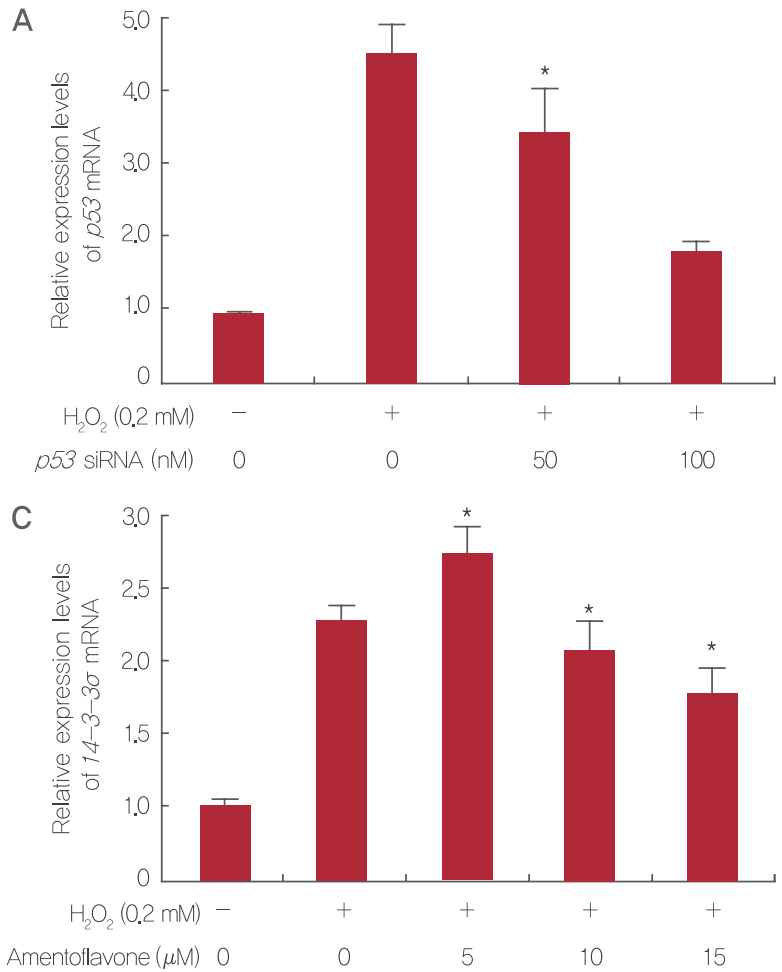

B

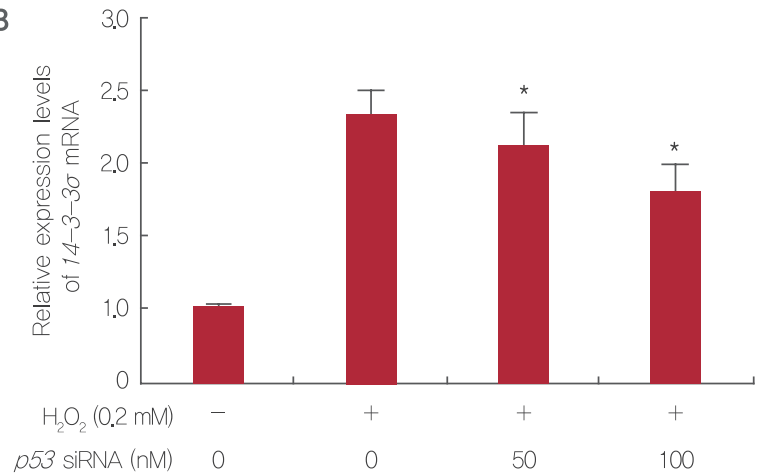

Figure 4. Effects of amentoflavone on 14-3-3 $\sigma$ mRNA expression.

The $14-3-3 \sigma$ is one of downstream target genes of $p 53$. The mRNA expression was determined by qRT-PCR. p53 siRNA transfection was conducted to make p53 knockdown condition. (A) The expression of p53 mRNA was reduced by p53 siRNA. (B) The expression of 14-3-3 $\sigma$ mRNA was decreased by p53 siRNA in a dose-dependent manner. (C) To confirm the effects of amentoflavone on 14-3-3 $\sigma$ mRNA expression, amentoflavone was treated with various concentrations. The expression of $14-3-3 \sigma$ mRNA was dose-dependently reduced. Values represent the mean $\pm S$.D. of three independent experiments. The Student's t-test was performed to determine statistical significance $\left({ }^{*} p<.05\right)$.

상기 결과는 기존에 발표된 amentoflavone의 $\mathrm{NF}-\kappa \mathrm{B}$ 활성 억 제 효과(Banerjee et al., 2002a; Woo et al., 2005; Ishola et al., 2013)의 연구결과와도 일치하며, amentoflavone이 산화 스트레스로 야기된 $\mathrm{NF}-\kappa \mathrm{B}$ 의 발현을 억제함으로써 downstream target인 TNF- $\alpha$, IL-6의 발현도 억제되 어 항염증 효과를 나타내는 것으로 사료된다.

\section{Effects of amentoflavone on p53 mRNA expression}

$\mathrm{H}_{2} \mathrm{O}_{2}$ 에 과도하게 노출될 경우 세포에서는 DNA를 보호하기 위 해 $p 53$ 유전자의 발현이 증가하고, downstream target 인 14-3-3o 유전자의 발현이 활성화됨으로써 cell cycle arrest가 유도되기도 하며, 세포 내 p53 유전자의 발현 증 가는 $\mathrm{ROS}$ 를 증가시켜 세포노화(cell senescence)를 유발 하기도 한다(Sasaki et al., 2008). 산화 스트레스가 유발된 $\mathrm{NHDF}$ 세포에서 amentoflavone이 p53 mRNA 발현에 미 치는 영향을 확인한 결과, amentoflavone을 처리하지 않고 $0.2 \mathrm{mM} \mathrm{H}_{2} \mathrm{O}_{2}$ 만 처리 시 대조군에 비해 $p 53$ 의 발현은 5.0 배 증가하였으나, amentoflavone을 $5,10,15 \mu \mathrm{M}$ 농도로 전
처리한 경우 $p 53$ 의 발현량은 4.3 배, 2.6배, 2.0 배 농도의존적으 로 감소하였다. 이는 amentoflavone의 전처리를 통해 NHDF 세포에 미치는 $\mathrm{H}_{2} \mathrm{O}_{2}$ 의 노출을 줄이고, 세포를 보호함으로써 $p 53$ 유전자의 발현이 억제된 것으로 판단된다(Figure 3).

\section{Effects of amentoflavone on 14-3-3 $\sigma$ mRNA expression}

$\mathrm{NHDF}$ 세포가 $\mathrm{H}_{2} \mathrm{O}_{2}$ 에 노출될 경우 세포의 $\mathrm{DNA}$ 를 보호 하기 위해 $p 53$ 유전자의 발현은 증가한다. $p 53$ 의 발현이 세 포 내 신호전달에 미치는 영향을 확인하고자 $p 53 \mathrm{siRNA}$ 를 사 용하여 p53 knockdown 조건을 만들었다. 먼저 p53 siRNA 가 $\mathrm{NHDF}$ 에서 정확하게 $p 53$ 발현을 억제하는지 확인한 결 과, $p 53$ siRNA를 형질주입 시키지 않고 $0.2 \mathrm{mM} \mathrm{H}_{2} \mathrm{O}_{2}$ 처리 시 $\mathrm{H}_{2} \mathrm{O}_{2}$ 와 $p 53 \mathrm{siRNA}$ 를 처리하지 않은 대조군에 비해 $p 53$ $\mathrm{mRNA}$ 발현이 4.6배 증가하였고 $p 53 \mathrm{siRNA}$ 를 $50,100 \mathrm{nM}$ 농도로 형질주입 시킨 후 $\mathrm{H}_{2} \mathrm{O}_{2}$ 를 처리 시 $p 53$ 발현이 3.5 배, 1.8 배로 농도의존적으로 감소하는 것을 확인할 수 있었다 (Figure 4A), p53 siRNA를 NHDF에 형질주입한 경우 p53 의 발현이 억제되었으므로, p53의 downstream에 있는 $14-$ 


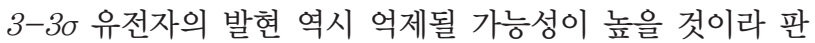
단하여 $p 53 \mathrm{siRNA}$ 를 형질주입하여 $14-3-3 \sigma$ 의 발현량을 확인하였다. NHDF에 p53 siRNA를 형질주입 하지 않고,

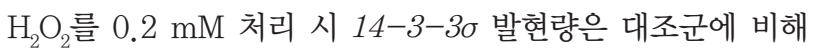
2.3 배 증가하였고, $p 53 \mathrm{siRNA}$ 를 $50,100 \mathrm{nM}$ 처리한 경우

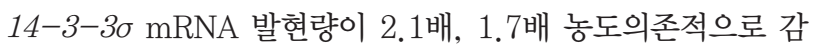
소하였다(Figure 4B). Amentoflavone이 14-3-30 유전자 발현에 미치는 영향에 대해 확인한 결과, NHDF에 $0.2 \mathrm{mM}$

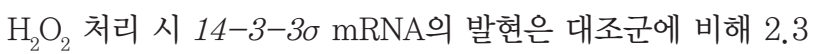
배 증가한 한편, amentoflavone을 $5,10,15 \mu \mathrm{M}$ 농도로 전 처리 하고 $0.2 \mathrm{mM} \mathrm{H}_{2} \mathrm{O}_{2}$ 를 처리한 경우 14-3-30 mRNA의 발현은 2.8 배, 2.1 배, 1.7 배 감소하는 것을 확인할 수 있었다

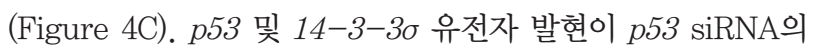
농도가 증가함에 따라 감소하는 동일한 경향을 나타냄으로써,

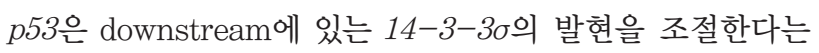
것을 실험적으로 확인할 수 있었다. 따라서 amentoflavone 을 전처리 한 후 $\mathrm{H}_{2} \mathrm{O}_{2}$ 처리 시, amentoflavone은 NHDF 세 포에 미치는 $\mathrm{H}_{2} \mathrm{O}_{2}$ 의 영향을 줄이고, 세포를 보호함으로써 $p 53$ 유전자의 발현을 억제하고 그 결과 downstream에 있는 14$3-3 \sigma$ 유전자의 발현을 억제한 것으로 판단된다.

\section{Effects of amentoflavone on cell cycle}

세포주기(cell cycle)는 세포의 자기 복제 과정이며 세포성장, 염색체 복제, 세포분열 등의 세부적인 과정이 있다(Heichman \& Roberts, 1994). 즉, 염색체의 복제가 일어나는 $\mathrm{S}$ 기, 염색체의 응축과 분리가 일어나는 $\mathrm{M}$ 기, $\mathrm{M}$ 기와 $\mathrm{S}$ 기 사이에 존재하는 $\mathrm{G} 1$ 기, $\mathrm{S}$ 기와 $\mathrm{M}$ 기 사이에 $\mathrm{G} 2$ 기가 존재한다. 이렇게 구분되는 세 포주기는 하나의 기(phase)가 완전히 완료되어야 다음 기로 진 행되는 특징을 갖고 있으며 이를 체크포인트(checkpoint)라고 한다(Hartwell \& Weinert, 1989). 세포주기를 조절하는 가장 중요한 인자로는 cyclin과 cyclin 의존성 인산화효소(cyclindependent kinase, $\mathrm{CDK}$ 로 이들 인자는 주기의 시작, 진행 및 완성을 담당하고 있다(Nurse, 1994). Amentoflavone에 의 한 p53 및 cell cycle arrest를 유도하는 14-3-36의 발현 억제 를 앞선 결과를 통해 확인함으로써, flow cytometry를 이용하 여 amentoflavone이 전처리된 $\mathrm{NHDF}$ 의 세포주기를 확인하였 다. Amentoflavone을 처리하지 않고 $\mathrm{H}_{2} \mathrm{O}_{2}$ 를 $0.2 \mathrm{mM}$ 만 처리 한 경우 amentoflavone과 $\mathrm{H}_{2} \mathrm{O}_{2}$ 를 모두 처리하지 않은 대조군 에 비해 G1기의 NHDF의 세포수 비율이 감소하고 sub-G1, $\mathrm{S}, \mathrm{G} 2 / \mathrm{M}$ 기의 세포수 비율이 모두 증가한 것으로 나타났다.

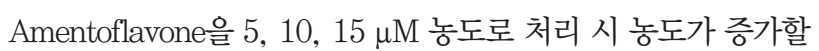
수록 G1기의 세포수 비율이 증가하고 sub-G1, S, G2/M기의 $\mathrm{NHDF}$ 는 세포수 비율이 감소하는 것으로 나타났다. 특히 G2/ $\mathrm{M}$ 기의 경우, $\mathrm{H}_{2} \mathrm{O}_{2}$ 만 처리시 대조군에 비해 $7.4 \%$ 증가한 반
면, amentoflavone을 농도별로 처리시 농도의존적으로 감소 하는 경향을 확인할 수 있었다(Figure 5). 상기 결과를 143-3ø가 G2/M기의 진행을 억제한다는 Hermeking et al. (1997)의 연구와 종합해서 고려해보면, $\mathrm{H}_{2} \mathrm{O}_{2}$ 로 인하여 $p 53$ 및 14-3-30의 발현이 증가함으로써 G2/M arrest가 발생하 여 해당기의 세포수 비율이 증가하였으나, amentoflavone 으로 인하여 $p 53$ 및 14-3-3o의 발현을 억제함으로써 G2/M arrest가 다시 회복되어 해당기의 세포수 비율이 감소한 것으로 사료된다. 즉, amentoflavone을 전처리 한 후 $\mathrm{H}_{2} \mathrm{O}_{2}$ 를 처리함 으로써, amentoflavone이 산화 스트레스를 줄여 세포를 보호

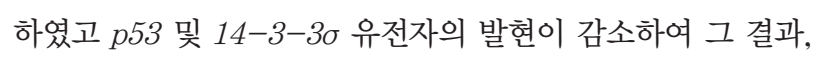
cell cycle arrest가 억제되어 $\mathrm{H}_{2} \mathrm{O}_{2}$ 처리전의 세포주기 상태로 회복된 것으로 판단된다.

\section{Conclusion}

산소 $\left(\mathrm{O}_{2}\right)$ 는 생체가 살아가기 위해 반드시 필요한 물질이지만, 생 체 내 대사과정에서 산화 스트레스를 유도하고 이 과정에서 생긴 활 성산소종(reactive oxygen species, ROS)이 세포 또는 조직에 상해를 준다는 것은 이미 많은 연구를 통해 보고되어왔다 (Halliwell, 1989; Yu, 1994; Hensley et al., 2000). 본연 구는 최근 발표한 amentoflavone의 항산화 및 항주름 효과(Lee $\& \mathrm{An}, 2016)$ 와 관련된 연구결과로, biflavonoid 종류 중 하나 인 amentoflavone의 항염 및 세포 보호 효과를 실험을 통해 검증 하고 화장품, 의약품 원료로서의 개발 가능성을 확인하기 위해 진행되었다.

Inflammatory cytokine인 $T N F-\alpha$ 와 $I L-6$ 의 유전자 발현량 과 관련하여, 단독으로 $\mathrm{H}_{2} \mathrm{O}_{2}$ 를 처리했을 때 $T N F-\alpha$ 와 $I L-6$ 의 발현량이 대조군에 비해 각각 6.9 배 및 7.4 배 증가했으나 amentoflavone 처리시 유의하게 감소하는 경향을 확인하였다. 또한, $\mathrm{H}_{2} \mathrm{O}_{2}$ 로 인하여 활성화된 $\mathrm{NF}-\kappa \mathrm{B}$ 의 발현이 amentoflavone $5,10,15 \mu \mathrm{M}$ 처리에 의해 4.2배, 3.7배, 2.3배 감소하였다. 이 는 amentoflavone이 산화 스트레스로 유도된 $\mathrm{NF}-\kappa \mathrm{B}$ 의 발 현을 억제함으로써 downstream target인 TNF- $\alpha, \mathrm{IL}-6$ 의 발 현을 억제하여 항염증 효과를 나타낸 것으로 판단된다. 한편, $\mathrm{H}_{2} \mathrm{O}_{2}$ 에 의해서 활성화된 p53 유전자의 발현을 amentoflavone 을 처리함으로써 4.3배, 2.6 배, 2.0 배로 농도의존적으로 억제시 켰으며, siRNA를 통해 확인한 p53 downstream target인 14$3-3 \sigma$ 유전자에서도 $\mathrm{H}_{2} \mathrm{O}_{2}$ 에 의해서 활성화된 14-3-3o 발현이 amentoflavone 처리에 의해 2.8배, 2.1배, 1.7 배로 농도의존

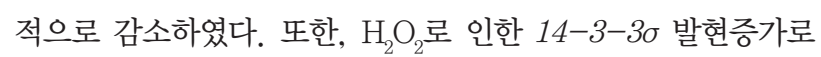
cell cycle arrest가 발생했으나, amentoflavone의 처리로 인 하여 $\mathrm{H}_{2} \mathrm{O}_{2}$ 처리 전의 세포주기 상태로 회복됨을 확인하였다. 


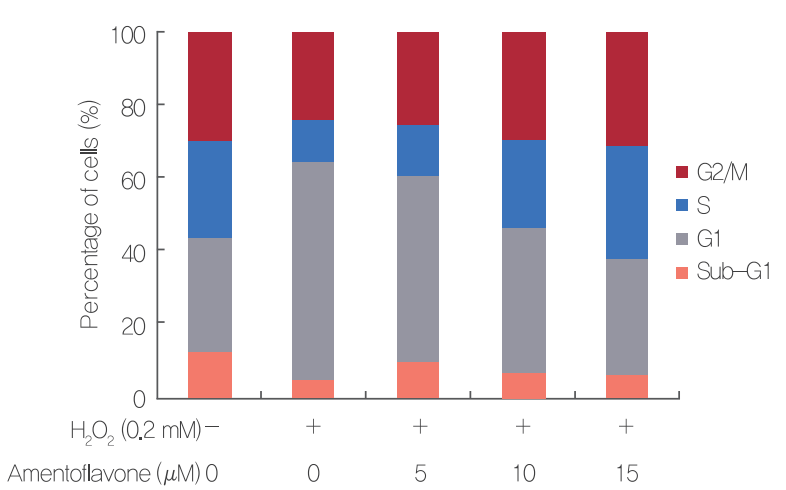

Figure 5. Effects of amentoflavone on cell cycle. The cell cycle was determined by flow cytometry using propidium iodide staining. After treatment of amentoflavone, $0.2 \mathrm{mM} \mathrm{H}_{2} \mathrm{O}_{2}$ was treated on NHDF cells. The percentage of $\mathrm{G} 1$ cells was dose-dependently increased by amentoflavone. However, the percentages of sub G1, S, and $\mathrm{G} 2 / \mathrm{M}$ were decreased. Values represent the mean \pm S.D. of three independent experiments.

상기 연구결과와 Lee \& An (2016)의 기존 연구결과를 통해, 항산화능을 가진 amentoflavone이 $\mathrm{H}_{2} \mathrm{O}_{2}$ 로 유발된 산화 스 트레스 상태에서, $\mathrm{TNF}-\alpha, \mathrm{IL}-6, \mathrm{NF}-\mathrm{\kappa B}$ 의 염증 관련 인자 들과 $p 53,14-3-3 \sigma$ 의 세포 손상 관련 유전자의 발현을 감소 시킬 뿐만 아니라 세포주기 회복 효과를 나타냄을 확인하였 다. 본 연구는 유전자 수준에서 각 효과를 확인했다는 제한점이 있으나, 연구결과를 종합적으로 고려해볼 때, amentoflavone 은 항염 및 세포 보호 기능을 나타내는 화장품 및 의약품 원료 로서의 충분한 개발 가능성이 있다고 사료된다.

\section{References}

Agarwal S, Drysdale BE, Shin HS. Tumor necrosis factormediated cytotoxicity involves ADP-ribosylation. The Journal of Immunology, 140: 4187-4192, 1988.

Ansel J, Perry P, Brown J, Damm D, Phan T, Hart C, Luger T, Hefeneider S. Cytokine modulation of keratinocyte cytokines. Journal of Investigative Dermatology, 94: 101-107, 1990.

Baeuerle PA, Henkel T. Function and activation of NFkappa B in the immune system. Annual Review of Immunology, 12: 141-179, 1994.

Baeuerle PA. Pro-inflammatory signaling: last pieces in the NF- $\mathrm{kB}$ puzzle? Current Biology, 8: 19-22, 1998.
Banerjee T, Van der Vliet A, Ziboh VA. Downregulation of COX -2 and iNOS by amentoflavone and quercetin in A549 human lung adenocarcinoma cell line. Prostaglandins, Leukotrienes and Essential Fatty Acids, 66: 485-492, 2002a.

Banerjee T, Valacchi G, Ziboh VA, Van der Vliet A. Inhibition of $\mathrm{TNF} \alpha$-induced cyclooxygenase-2 expression by amentoflavone through suppression of $\mathrm{NF}-\kappa \mathrm{B}$ activation in A549 cells. Molecular and Cellular Biochemistry, 238: 105-110, 2002b.

Brown JP, Wei W, Sedivy JM. Bypass of senescence after disruption of $\mathrm{p} 21^{\text {CIPI/WAFI }}$ gene in normal diploid human fibroblasts. Science, 277: 831-834, 1997.

Guruvayoorappan C, Kuttan G. Inhibition of tumor specific angiogenesis by amentoflavone. Biochemistry (Moscow), 73: 209-218. 2008.

Halliwell B. Free radicals, reactive oxygen species and human disease: a critical evaluation with special reference to atherosclerosis. British Journal of Experimental Pathology, 70: 737-757, 1989.

Hartwell LH, Weinert TA. Checkpoints: controls that ensure the order of cell cycle events. Science, 246: 629-634, 1989.

Heichman KA, Roberts JM. Rules to replicate by. Cell, 79: 557-562, 1994.

Hensley K, Robinson KA, Gabbita SP, Salsman S, Floyd RA. Reactive oxygen species, cell signaling, and cell injury. Free Radical Biology and Medicine, 28: 1456-1462, 2000.

Hermeking H, Lengauer C, Polyak K, He TC, Zhang L, Thiagalingam S, Kinzler KW, Vogelstein B. 14-3-3sigma is a p53-regulated inhibitor of G2/M progression. Molecular Cell, 1: 3-11, 1997.

Hwang BJ, Ford JM, Hanawalt PC, Chu G. Expression of the p48 xeroderma pigmentosum gene is p53dependent and is involved in global genomic repair. Proceedings of the National Academy of Sciences of the United States of America, 96: 424-428, 1999.

Hwang JH, Choi HM, Woo ER, Lee DG. Antibacterial effect of amentoflavone and its synergistic effect with antibiotics. Journal of Microbiology and Biotechnology, 23: 953-958, 2013.

Ishola IO, Chatterjee M, Tota S, Tadigopulla N, Adeyemi OO, Palit G, Shukla R. Antidepressant and anxiolytic 
effects of amentoflavone isolated from Cnestis ferruginea in mice. Pharmacology Biochemistry and Behavior, 103: 322-331, 2012.

Ishola IO, Chaturvedi JP, Rai S, Rajasekar N, Adeyemi OO, Shukla R, Narender T. Evaluation of amentoflavone isolated from Cnestis ferruginea Vahl ex DC (Connaraceae) on production of inflammatory mediators in LPS stimulated rat astrocytoma cell line (C6) and THP-1 cells. Journal of Ethnopharmacology, 146: 440-448, 2013.

Jones SN, Roe AE, Donehower LA, Bradley A. Rescue of embryonic lethality in Mdm2-deficient mice by absence of p53. Nature, 378: 206-208, 1995.

Jung HJ, Sung WS, Yeo SH, Kim HS, Lee IS, Woo ER, Lee DG. Antifungal effect of amentoflavone derived from Selaginella tamariscina. Archives of Pharmacal Research, 29: 746-751, 2006.

Kim HK, Son KH, Chang HW, Kang SS, Kim HP. Amentoflavone, a plant biflavone: a new potential anti-inflammatory agent. Archives of Pharmacal Research, 21: 406-410, 1998.

Kim JS, Kim KL. Anti-oxidative and anti-inflammatory effects of Artemisiae Capillaris extract. Korean Journal of Aesthetics and Cosmetology, 13: 805812, 2015.

Kortlever RM, Higgins PJ, Bernards R. Plasminogen activator inhibitor -1 is a critical downstream target of p53 in the induction of replicative senescence. Nature Cell Biology, 8: 877-884, 2006.

Lee JS, Sul JY, Park JB, Lee MS, Cha EY, Song IS, Kim JR, Chang ES. Fatty acid synthase inhibition by amentoflavone suppresses HER2/neu (erbB2) oncogene in SKBR3 human breast cancer cells. Phytotherapy Research, 27: 713-720, 2013.

Lee SJ, An S. Antioxidant and antiwrinkle effects of amentoflavone for cosmetic materials development. Asian Journal of Beauty and Cosmetology, 14: 66-76, 2016.

Levine AJ. p53, the cellular gatekeeper for growth and division. Cell, 88: 323-331, 1997.

Longley BJ, Braverman IM, Edelson RL. Immunology and the skin: current concepts. Annals of the New York Academy of Sciences, 548: 225-232, 1988.

Mazière C, Conte MA, Degonville J, Ali D, Mazière JC.
Cellular enrichment with polyunsaturated fatty acids induces an oxidative stress and activates the transcription factors AP1 and $\mathrm{NF} \kappa \mathrm{B}$. Biochemical and Biophysical Research Communications, 265: 116122, 1999.

Miliani de Marval PL, Zhang YP. The RP-Mdm2-p53 pathway and tumorigenesis. Oncotarget, 2: 234238, 2011.

Miyashita T, Krajewski S, Krajewska M, Wang HG, Lin HK, Liebermann DA, Hoffman B, Reed JC. Tumor suppressor p53 is a regulator of bcl-2 and bax gene expression in vitro and in vivo. Oncogene, 9: 17991805, 1994

Montes de Oca Luna R, Wagner DS, Lozano G. Rescue of early embryonic lethality in mdm2-deficient mice by deletion of p53. Nature, 378: 203-206, 1995.

Nathan CF. Secretory products of macrophages. The Journal of Clinical Investigation, 79: 319-326, 1987.

Nomoto Y, Yamamoto M, Fukushima T, Kimura H, Ohshima K, Tomonaga M. Expression of nuclear factor kappaB and tumor necrosis factor alpha in the mouse brain after experimental thermal ablation injury. Neurosurgery, 48: 158-166, 2001.

Nurse P. Ordering S phase and M phase in the cell cycle. Cell, 79: 547-550, 1994.

Oh JH, Chung AS, Steinbrenner H, Sies H, Brenneisen P. Thioredoxin secreted upon ultraviolet A irradiation modulates activities of matrix metalloproteinase-2 and tissue inhibitor of metalloproteinase-2 in human dermal fibroblasts. Archives of Biochemistry and Biophysics, 423: 218-226, 2004.

Opal SM, DePalo VA. Anti-inflammatory cytokines. Chest, 117: 1162-1172, 2000.

Park NH, Lee CW, Bae JH, Na YJ. Protective effects of amentoflavone on Lamin A-dependent UVB-induced nuclear aberration in normal human fibroblasts. Bioorganic \& Medicinal Chemistry Letters, 21: 6482-6484, 2011.

Radák Z, Chung HY, Naito H, Takahashi R, Jung KJ, Kim HJ, Goto S. Age-associated increases in oxidative stress and nuclear transcription factor $\mathrm{\kappa B}$ activation are attenuated in rat liver by regular exercise. The FASEB Journal, 18: 749-750, 2004.

Rostasy K, Monti L, Yiannoutsos C, Wu J, Bell J, Hedreen 
J, Navia BA. NF $\kappa$ B activation, TNF- $\alpha$ expression, and apoptosis in the AIDS-Dementia-Complex. Journal of Neurovirology, 6: 537-543, 2000.

Rothblum-Oviatt CJ, Ryan CE, Piwnica-Worms H. 14-3-3 binding regulates catalytic activity of human Wee1 kinase. Cell Growth \& Differentiation, 12: 581589, 2001.

Sasaki M, Ikeda H, Sato Y, Nakanuma Y. Proinflammatory cytokine-induced cellular senescence of biliary epithelial cells is mediated via oxidative stress and activation of ATM pathway: a culture study. Free Radical Research, 42: 625-632, 2008.

Smits VAJ, Medema RH. Checking out the $\mathrm{G}_{2} / \mathrm{M}$ transition. Biochimica et Biophysica Acta, 1519: 1-12, 2001.
Wilsky S, Sobotta K, Wiesener N, Pilas J, Althof N, Munder T, Wutzler P, Henke A. Inhibition of fatty acid synthase by amentoflavone reduces coxsackievirus B3 replication. Archives of Virology, 157: 259-269, 2012.

Woo ER, Lee JY, Cho IJ, Kim SG, Kang KW. Amentoflavone inhibits the induction of nitric oxide synthase by inhibiting $\mathrm{NF}-\kappa \mathrm{B}$ activation in macrophages. Pharmacological Research, 51: 539-546, 2005.

Yu BP. Cellular defenses against damage from reactive oxygen species. Physiological Reviews, 74: 139162, 1994. 


\section{국문초록}

\section{Amentoflavone의 항염증 및 세포 보호 효과}

이송정 ${ }^{1}$ 한효선 ${ }^{2}$, 안인숙 ${ }^{2}$, 안규중 ${ }^{3 *}$

${ }^{1}$ 건국대학교 생물공학과, 서울, 한국

${ }^{2}$ 한국피부임상과학연구소, 충청북도 청주시, 한국

${ }^{3}$ 건국대학교 의학전문대학원 피부과학교실, 서울, 한국

목적: 본 연구의 목적은 amentoflavone의 항염증 및 세포 보호 효과를 확인하여 화장품, 의약품 원료로서의 가능성을 검증하는데 있다.

방법: Amentoflavone의 항염증 효과를 확인하기 위하여, $\mathrm{qRT}-\mathrm{PCR}$ 를 이용하여 TNF- $\alpha$, $\mathrm{L}-6$ 와 같은 inflammatory cytokine의 발현량 을 측정하였다. 그리고 $\mathrm{NF}-\kappa \mathrm{B}$ 의 발현량을 확인하기 위해 $\mathrm{NF}-\mathrm{\kappa B}$ promoter luciferase assay를 수행하였다. 세포 보호 효과를 확인하기 위해서, $p 53$ siRNA transfection을 수행하여 $p 53$ 과 14-3-30의 상관관계를 확인하였고, cell cycle analysis를 통해 amentoflavone 이 14-3-30 mRNA 발현 및 cell cycle arrest에 미치는 영향을 확인하였다.

결과: $\mathrm{TNF}-\alpha, \mathbb{L}-6$ 및 NF- $\mathrm{KB}$ 와 같은 염증관련 인자들의 발현은 amentoflavone에 의해 농도의존적으로 감소하였다. 세포 보호와 관련 해서, amentoflavone의 p53 mRNA 발현 억제 효과를 확인하였고, $p 53$ siRNA transfection을 통해 $p 53$ 와 $14-3-3 \sigma$ 의 양의 상관관계를 확인하였다. 또한, amentoflavone에 의해 14-3-30 mRNA의 발현이 감소함에 따라, cell cycle arrest 상태에서 cell cycle progression 상태로 회복되었다.

결론: 상기 연구에 따르면, amentoflavone은 염증 및 세포 손상에 영향을 주는 인자들의 발현을 억제하고, cell cycle progression 을 회복시키는 효과가 있음을 알 수 있다. 따라서 항염증 및 세포 보호 효과를 가진 amentoflavone은 화장품 및 의약품 원료로서 활용 가능할 것으로 사료된다.

핵심어: Amentoflavone, 항염증, 세포 보호, 산화 스트레스, 인간진피섬유아세포

\section{참고문헌}

김정숙, 김금란. 인진호 추출물의 항산화활성 및 항염효과. 대한피부미용학회지, 13: 805-812, 2015.

이송정, 안성관. 화장품 소재 개발을 위한 amentoflavone의 항산화 및 항주름 효과 연구. 아시안뷰티화장품학술지, 14: 66-76, 2016. 


\section{中文摘要}

\section{Amentoflavone的抗炎症及细胞保护效果}

李松靜 ${ }^{1}$, 韓孝仙 $\left.\right|^{2}$, 安仁淑 ${ }^{2}$, 安圭重 ${ }^{3 *}$

${ }^{1}$ 建国大学校生物工学科, 首尔, 韩国

2韩国皮肤临床科学研究所, 忠淸北道清州市, 韩国

建国大学 医科大学 皮肤科, 首尔, 韩国

目的: 探讨amentoflavone的抗炎症以及细胞保护效果，鉴定作为医药品原料的适用可行性。

方法: 为了确认amentoflavone的抗炎症效果, 利用qRT-PCR测定像TNF- $\alpha$ ，IL-6等炎性细胞因子的表达。NF-kB的表达量通过 实施NF-kB promoter luciferase assay实验而确定。为了确认 amentoflavone的细胞保护效果, 实施了 $p 53$ siRNA transfection从 而确定了 $p 53$ 和14-3-3 $\sigma$ 的相互关系。通过 cell cycle分析探讨amentoflavone对14-3-3 $\sigma$ mRNA表达以及cell cycle arrest的影响。 结果: 以 $\mathrm{H}_{2} \mathrm{O}_{2}$ 诱导的氧化应激状态中, 利用amentoflavone处理时, 细胞的生存率随着amentoflavone浓度的增加而提高, 而 像TNF- $\alpha$ ，IL-6 和 NF-KB等炎症因子的表达随着浓度增加而减少了。关于细胞保护效果，amentoflavone对 p53 mRNA表达具 有抑制效果以及通过 $p 53$ siRNA transfection确定了 p53和 14-3-30的相互关系。Amentoflavone降低了14-3-30 mRNA的表达, 同时细胞从周期停滞状态恢复到细胞周期行进状态中。

结论: 通过以上的研究, amentoflavone提高了细胞生存率, 对参与炎症及细胞损伤相关的基因因子的表达具有抑制效以及具 有恢复细胞周期行进状态的效果。因此具有抗炎症以及细胞保护效果的amentoflavone作为化妆品以及医药品的原料充分具有 可行性。

关键词: Amentoflavone, 抗炎症, 保护细胞, 氧化应激, 人体真皮纤维细胞 